九州大学学術情報リポジトリ

Kyushu University Institutional Repository

\title{
Biological Activities of Benzimidazole Derivatives from Amino Acids
}

Ohtani, Jiro

Laboratory of Pesticide Chemistry, Faculty of Agriculture, Kyushu University

Maekawa, Kazuyuki

Laboratory of Pesticide Chemistry, Faculty of Agriculture, Kyushu University

https://doi.org/10.5109/23496

出版情報: 九州大学大学院農学研究院紀要. 21 (4)，pp. 161-166，1977-07. Kyushu University バージョン：

権利関係 : 


\title{
Biological Activities of Benzimidazole Derivatives from Amino Acids
}

\author{
Jiro Ohtani and Kazuyuki Maekawa \\ Laboratory of Pesticide Chemistry, Faculty of Agriculture, \\ Kyushu University 46-02, Fukuoka 812
}

(Received January 12, 1977)

The regression analysis was attempted as to biologically active compounds among the benzimidazole derivatives derived from amino acids. As a result, it seems to be necessary for the phytotoxic activity that side chains of amino acids contain nitrogen as a hetero atom and the number of carbon between a-carbon and the hetero atom is two.

Naturally occurring amino acids and some peptides were led to benzimidazole derivatives by incorporating their carboxyl groups into benzimidazole ring by the reaction with o-phenylenediamine (Maekawa and Ohtani, 1976, 1977).

These derivatives of amino acids and peptides had remarkable phytotoxicities. However, while benzimidazole derivatives from dipeptides showed generally only slight inhibition on the growth of plants at lower concentrations than $10 \mathrm{ppm}, Z$-Asp*-[B] $]^{\#}$ inhibited intensely the growth of radish and Glu*- [B] exhibited the remarkable activity on the root growth of rice (Table 1). Thus, the application for a lasting pesticide might be possible. That is to say, benzimidazole derivative from peptide will be decomposed in soil to give suitable amino acids*-[B], and thus, the resulting active compound may inhibit the growth of plants.

In the present paper, the regression analysis was attempted to the results of the examination carried out on the root growth of radish.

\section{EXPERIMENTAL}

\section{Evaluation of phytotoxic effects on seedling growth}

Compounds applied were synthesized by the authors. Since these preparations were not so soluble in water, they were adopted as an acetone solution. Namely, each $5 \mathrm{mg}$ of the compound was dissolved in $50 \mathrm{ml}$ of acetone, $10 \mathrm{ml}$ of which (or further diluted solution with acetone) was poured into a Petri-dish (diameter $9 \mathrm{~cm}$ ) placed beforehand a filter paper. After evaporating the solvent, $10 \mathrm{ml}$ of water was added to the dish, followed by adding seeds.

Twenty seeds of rice or radish were used after immersing them in water

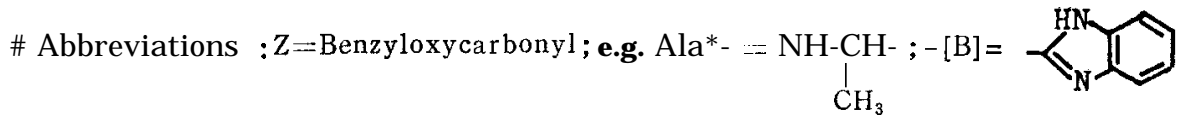


Table 1. Inhibition on germianation and seeling growth of radish and rice by benzimidazole derivatives.

\begin{tabular}{|c|c|c|c|c|c|c|c|c|}
\hline & $\begin{array}{l}\text { Conc. } \\
\text { (ppm) }\end{array}$ & & $\mathrm{Z}-\mathrm{Asp}-{ }^{*}[\mathrm{~B}]$ & Z-Glu-* [ B ] & Z-Thr-* $[\mathrm{B}]$ & $Z-\operatorname{Trp}-$ & [B] & $\mathrm{H}$-Glu-* $[\mathrm{B}]$ \\
\hline \multirow{6}{*}{ Radish } & 100 & $\begin{array}{l}\mathrm{R} \\
\mathrm{S}\end{array}$ & $\begin{array}{ll}H & Y \\
H & Y\end{array}$ & 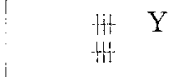 & $\begin{array}{l}\text { in } \\
\text { 棤 }\end{array}$ & $\begin{array}{l}\text { HH } \\
\text { Ht }\end{array}$ & & $\therefore$ \\
\hline & 30 & $\begin{array}{l}\mathrm{R} \\
\mathrm{S}\end{array}$ & $\begin{array}{ll}H & Y \\
H & Y\end{array}$ & $\begin{array}{l}H \\
+1\end{array}$ & - & 卅 & $\mathrm{Y}$ & -- \\
\hline & 10 & $\begin{array}{l}\mathrm{R} \\
\mathrm{S}\end{array}$ & $\begin{array}{ll}\text { tit } & Y \\
\text { Htt } & \end{array}$ & - & - & $\underset{H}{H}$ & & $\ldots$ \\
\hline & 5 & $\begin{array}{l}\mathrm{R} \\
\mathrm{S}\end{array}$ & $\begin{array}{l}\text { H } \\
H\end{array}$ & & & + & & \\
\hline & 2 & $\begin{array}{l}\mathrm{R} \\
\mathrm{S}\end{array}$ & $\begin{array}{l}+ \\
H\end{array}$ & & & "' & & \\
\hline & 0.5 & $\begin{array}{l}\mathrm{R} \\
\mathrm{S}\end{array}$ & ${ }^{\prime \prime}$ & & & - & & \\
\hline \multirow{6}{*}{ Rice } & 100 & $\begin{array}{l}\mathrm{R} \\
\mathrm{S}\end{array}$ & HI & $\begin{array}{l}H- \\
H\end{array}$ & H & - & & $\begin{array}{l}x \\
\frac{1}{i}\end{array}$ \\
\hline & 30 & $\begin{array}{l}\mathrm{R} \\
\mathrm{S}\end{array}$ & $\begin{array}{c}1 ! \\
\vdots \\
\vdots \\
\cdots\end{array}$ & $\begin{array}{l}- \\
\vdots \\
i-\end{array}$ & $\begin{array}{l}H \\
+\end{array}$ & $\begin{array}{l}H \\
H\end{array}$ & & $\begin{array}{l}x \\
\text { Ht }\end{array}$ \\
\hline & 10 & $\begin{array}{l}\mathrm{R} \\
\mathrm{S}\end{array}$ & $\begin{array}{l}+ \\
+\end{array}$ & $\begin{array}{l}H \\
H\end{array}$ & $\begin{array}{l}+ \\
-H \\
\end{array}$ & $\begin{array}{l}\text { H } \\
+1\end{array}$ & & $\begin{array}{l}\text { H } \\
H\end{array}$ \\
\hline & 5 & $\begin{array}{l}\mathrm{R} \\
\mathrm{S}\end{array}$ & 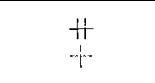 & - & $\bar{t}$ & - & & +1 \\
\hline & 2 & $\begin{array}{l}\mathrm{R} \\
\mathrm{S}\end{array}$ & - & - & " & - & & - \\
\hline & 0.5 & $\begin{array}{l}\mathrm{R} \\
\mathrm{S}\end{array}$ & - & - & - & - & & - \\
\hline
\end{tabular}

R, Root; S, Stem; Y, Yellow.

$X$ : Complete inhibition.

IIt: $60 \%$ or higher inhibition.

H : 30-60 \% inhibition.

t: $30 \%$ or lower inhibition.

- : No inhibition on germination and seedling growth.

": Stimulation of germination.

for 1 day. These seeds were kept at $25^{\circ} \mathrm{C}$ for a certain time interval (4 days for radish, and 11 days for rice). The evaluation of activity was made by examining the rate of growth inhibition or stimulation on both of stem and root. The experiments with diluted solution were repeated twice.

Partition coefficients and substituent constant $\left(\beta_{0}\right)$

A mixture of $5 \mathrm{mg}$ of the benzimidazole derivative, $10 \mathrm{ml}$ of ethyl acetate, and $50 \mathrm{ml}$ of water was shaken in a separating funnel at room temperature 
for 5 minutes, then was allowed to stand for 1 hour. After the ethyl acetate layer was concentrated in vacuo, the UV absorbance at $280 \mathrm{~nm}$ was measured to get the partition coefficient $(\mathrm{P})$.

$$
\mathrm{P}=\frac{\mathrm{A}_{280 \mathrm{~nm}} \text { of AcOEt solution }}{\mathrm{A}_{\text {2080 }} \text { of } \text { water solution }}
$$

Substituent constant $\left(\beta_{0}\right)$ was calculated as follows.

$$
\beta_{0}=\log \mathrm{P}-\log \mathrm{P}_{\mathrm{Giy}}
$$

$\mathrm{P}$ is a partition coefficient of Z-amino acid*-[B] and $\mathrm{P}_{\mathrm{Gly}}$ is that of $\mathrm{Z}$-Gly $*_{-}[\mathrm{B}]$.

\section{RESULTS}

'The substituent constants $\left(\beta_{0}\right)$ obtained from ethyl acetate-water system and the concentrations (ppm) for $50 \%$ inhibition are summarized in Table 2.

Table 2. Data for regression analysis.

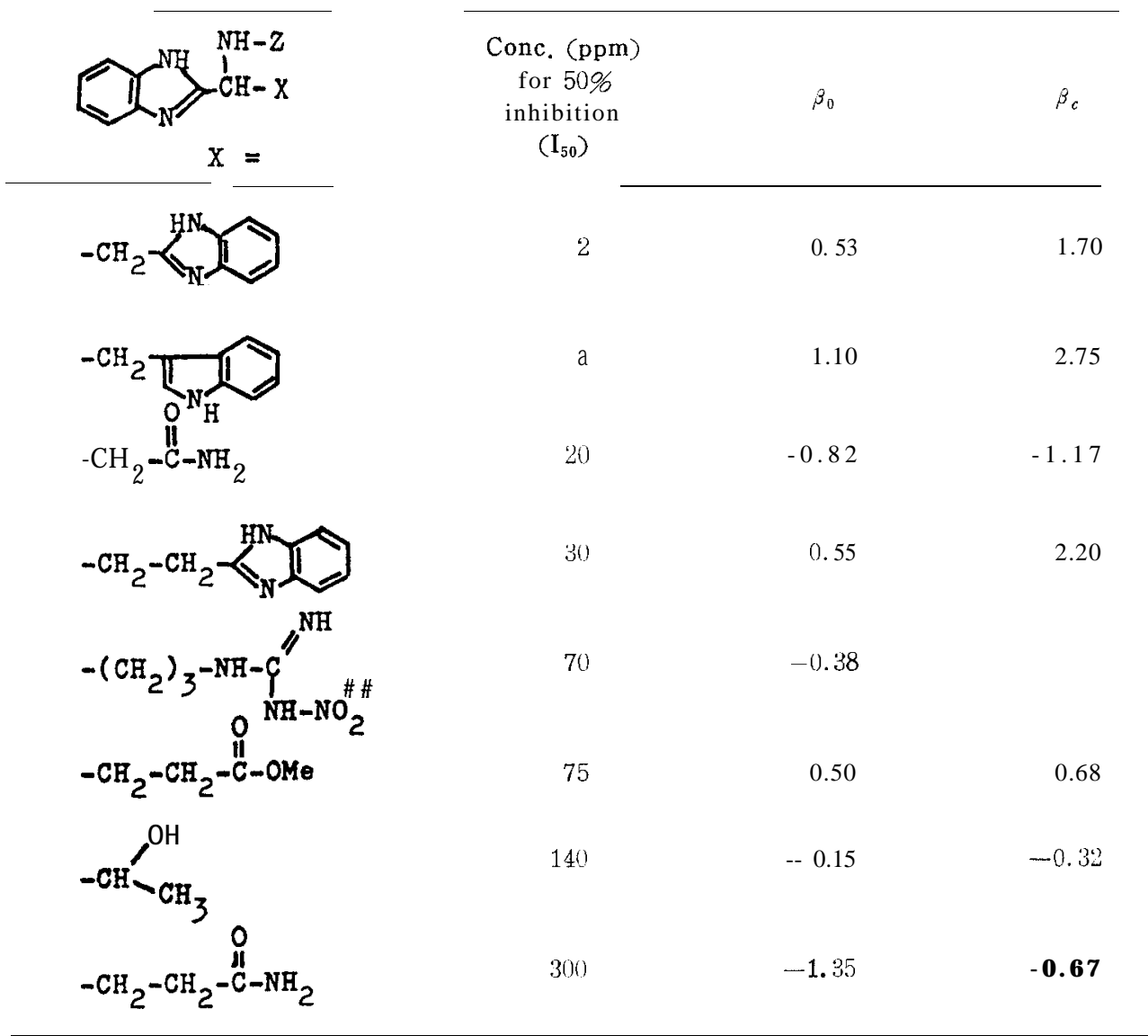

$\# \#$ refer to Z-Arg $\stackrel{*}{*}-[B]$ 
The relationship between $\log 1 / I_{50}$ and $\beta_{0}$ is shown in Eq. (1) and Fig. l-a. In Fig. 1-a, both Z-Asp*-[B] and Z-Asn*- [B] which are far distant from Eq. (1) possess two carbons between the a-carbon and the herero atom.

$$
\log 1 / I_{50}=0.53 \beta_{0}-1.54
$$

$\begin{array}{ll}\mathrm{n} & \mathrm{r} \\ 8 & 0.624\end{array}$

On the other hand, both of Z-Thr*-[B] and Z-Glu*( $\gamma-\mathrm{OMe}) \cdot[\mathrm{B}]$ have not nitrogen, but oxygen as a hetero atom. It was assumed that two as to the number of carbon was favorable for the activity and oxygen as a hetero atom was not good for it. So, +1.4 was added to $\beta_{0}$ in the former case and the contribution of -1 was considered in the latter case. Thus, an altered parameter was named $\beta_{0} *$ and then Eq. (2) and Fig. l-b was obtained.

$$
\log 1 / I_{50}=0.62 \beta_{0}^{*}-1.60
$$

$\begin{array}{ll}\mathrm{n} & \stackrel{\mathrm{r}}{8} \\ 8 & 0.993\end{array}$
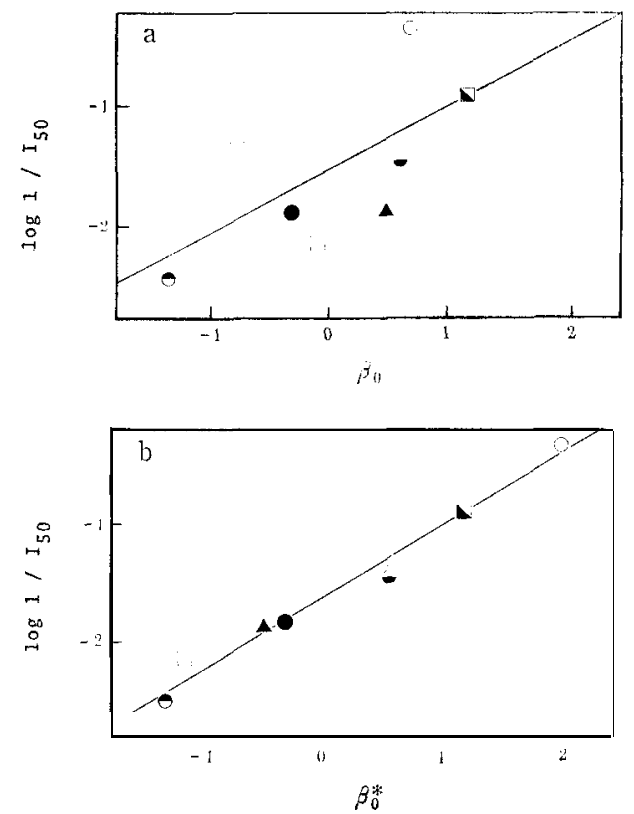

Fig. 1. The relationship between chemical structure and herbicidal activity on radish (refer to Eqs. 1 and 2).
Z-Arg ${ }_{(\alpha)}^{*}-[\mathrm{B}]$
$\triangle \mathrm{Z}-\mathrm{Asn}{ }^{*}-[\mathrm{B}]$
Z-Asp"- [B]
Z-Gln*-[B]
Z-Glu*. [B]
Z-Trp*- $[\mathrm{B}]$
$\Delta \mathrm{Z}-\mathrm{Glu}^{*}(\gamma-\mathrm{OMe})-[\mathrm{B}]$

Then, the relationship between the substituent constants $\left(\boldsymbol{\beta}_{c}\right)$ calculated from the data of Hansch-Fujita (Leo et al., 1971) in octanol-water system and $\log 1 / I_{50}$ was illustrated in Eq. (3) and Fig. 2-a. 

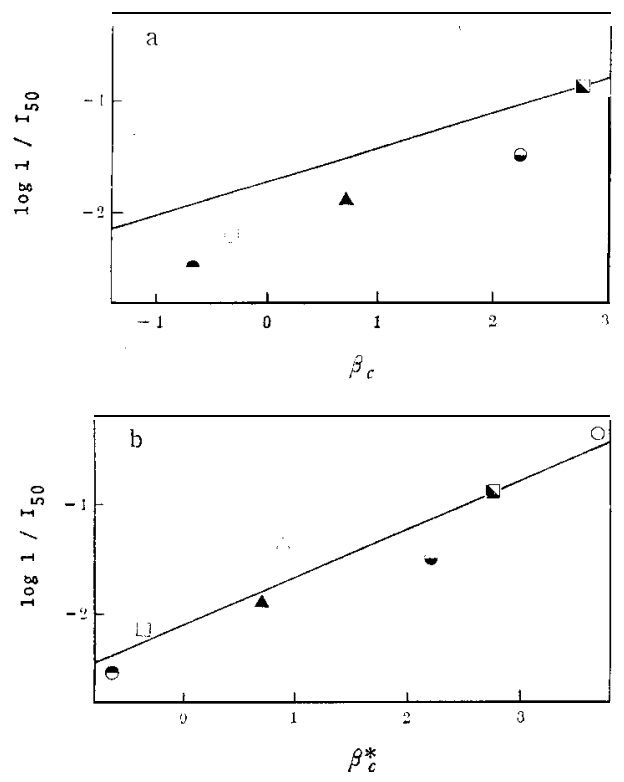

Fig. 2. The relationship between chemical structure and herbicidal activity on radish (refer to Eqs. 3 and 4).

$$
\begin{array}{lll}
\log \mathrm{l} / \mathrm{I},=0.30 \beta_{c}-1.72 & & \\
& \mathrm{n} & \mathrm{r} \\
& & 0.600
\end{array}
$$

In the similar manner described above, if +2 was added to $\beta_{c}$ in the case that the number of carbon was two, so Eq. (4) and Fig. 2-b was given from $\log 1 / I_{50}$ and $\beta_{c}{ }^{*}$ (new parameter).

$$
\log 1 / I_{50}=0.43 \beta_{c}^{*}-2.06
$$

$\begin{array}{ll}\mathbf{n} & \mathbf{r} \\ 7 & 0.923\end{array}$

The function was determined using three kinds of parameters, I,,, $\beta_{0}$, and $\mathrm{n}$ (Eq. (5)). Here, $\mathrm{n}$ was defined as +1 when the number of carbon was two and as 0 in the other cases.

$$
\log 1 / \mathrm{I}_{50}=0.75 \beta_{0}+3.45 \mathrm{n}-2.40
$$

$\begin{array}{ll}\mathrm{n} & \mathrm{r} \\ 8 & 0.864\end{array}$

The relationship between $\log 1 / \mathrm{I}_{50}$ and $0.75 \beta_{0}+3.45 \mathrm{n}$ is plotted in Fig. 3 . The coefficient of a parameter for the number of carbon is 3.45 and it is very high.

From the results described above, it seems to be necessary for higher activities that side chains of amino acids contain nitrogen as a hetero atom and the number of carbon between $\alpha$-carbon and a hetero atom is two. 


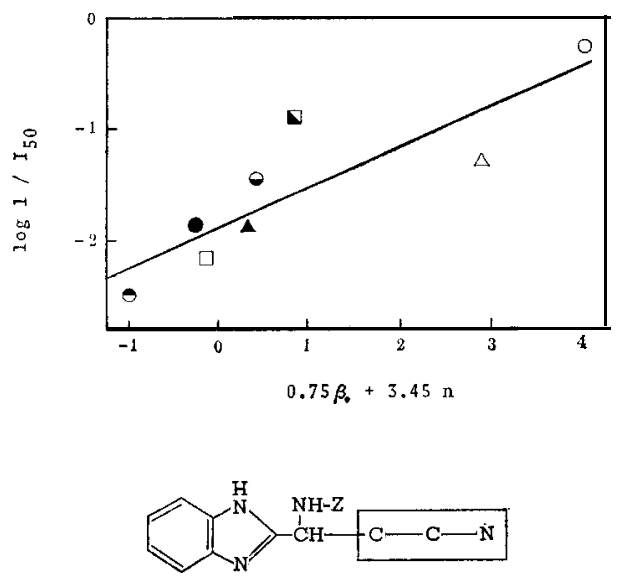

Fig. 3. The relationship between chemical structure and herbicidal activity on radish (refer to Eq. 5) and a proposed structure for higher activity.

\section{REFERENCES}

Leo, A., C. Hansch and D. Elkins 1971 Partition coefficients and their uses. Chem. Rev., 71: $525-616$

Maekawa, K. und J. Ohtani 1976 Synthese von 2-(1'-Amino-1'-substituiertem alkyl)-benzimidazol aus Aminosäuren und Ihre Biologische Aktivitit. Agric. Biol. Chem., 40: 791-799

Maekawa, K. and J. Ohtani 1977 Synthesis and biological activities of benzimidazole derivatives from peptides. Agric. Biol. Chem., 41: 811-818 